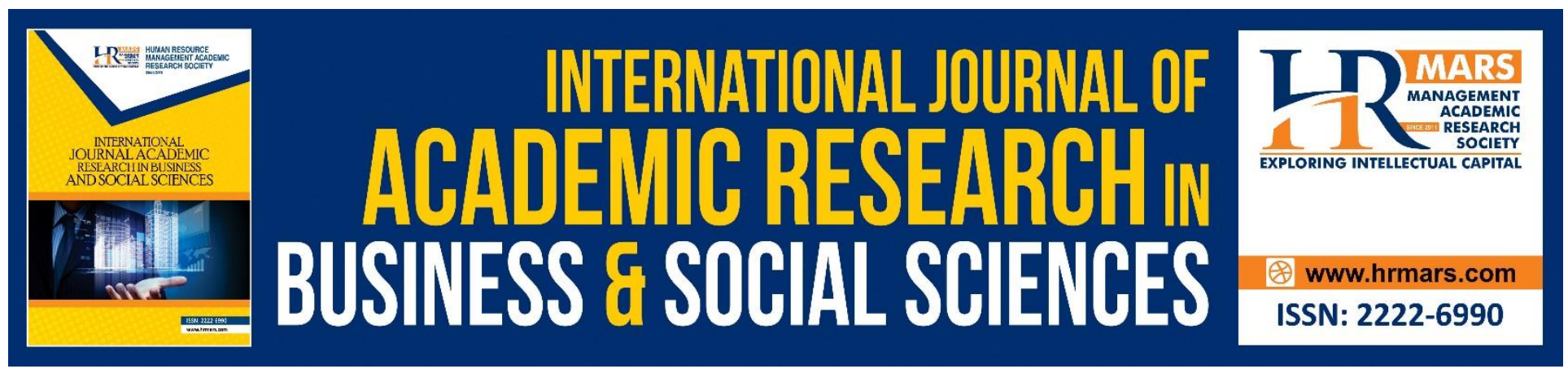

\title{
Corporate Social Responsibility and Stock Price Market of Selected Listed Companies in Nigeria
}

Olaoye, Oladipupo Festus \& Oluwadare, Oladimeji Emmanuel

To Link this Article: http://dx.doi.org/10.6007/IJARBSS/v8-i7/4425

DOI: $\quad 10.6007 /$ IJARBSS/v8-i7/4425

Received: 27 May 2018, Revised: 23 June 2018, Accepted: 29 June 2018

Published Online: 28 July 2018

In-Text Citation: (Olaoye \& Oluwadare, 2018)

To Cite this Article: Olaoye, O. F., \& Oluwadare, O. E. (2018). Corporate Social Responsibility and Stock Price Market of Selected Listed Companies in Nigeria. International Journal of Academic Research in Business and Social Sciences, 8(7), 872-886.

Copyright: (C) 2018 The Author(s)

Published by Human Resource Management Academic Research Society (www.hrmars.com)

This article is published under the Creative Commons Attribution (CC BY 4.0) license. Anyone may reproduce, distribute, translate and create derivative works of this article (for both commercial and non-commercial purposes), subject to full attribution to the original publication and authors. The full terms of this license may be seen at: http://creativecommons.org/licences/by/4.0/legalcode

Vol. 8, No. 7, July 2018, Pg. 872 - 886

Full Terms \& Conditions of access and use can be found at http://hrmars.com/index.php/pages/detail/publication-ethics 


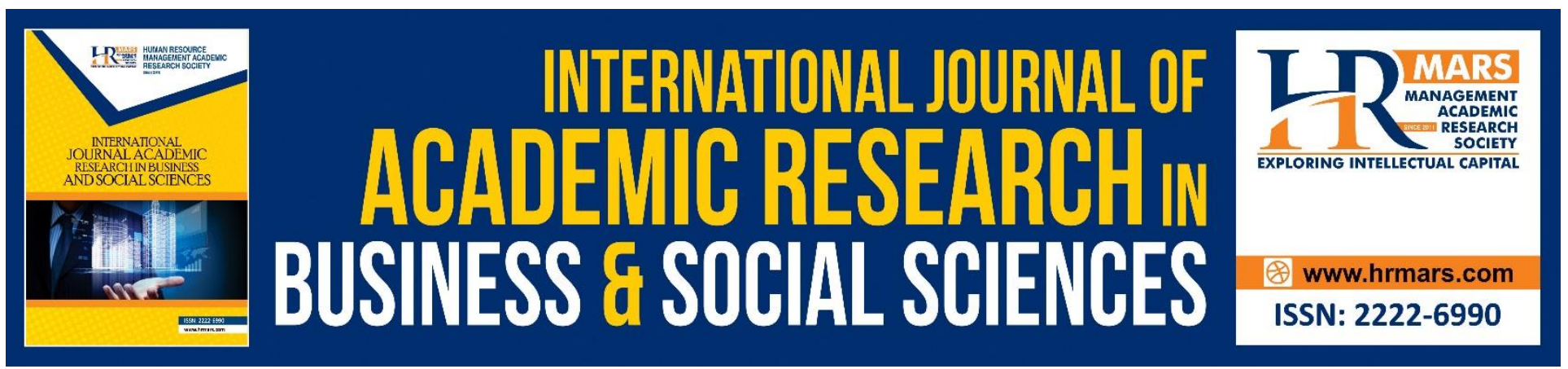

\title{
Corporate Social Responsibility and Stock Price Market of Selected Listed Companies in Nigeria
}

\author{
Olaoye, Oladipupo Festus (Ph.D.) \\ Department of Accounting, Management Sciences, Ekiti State University, Ado Ekiti \\ Email: oladipupo.olaoye@eksu.edu.ng \\ Oluwadare, Oladimeji Emmanuel \\ Department of Accounting, Management Sciences, Ekiti State University, Ado Ekiti \\ Email: oladimejioluwadare76@gmail.com
}

\begin{abstract}
This paper examines corporate social responsibility and stock price market of selected listed companies in Nigeria. Specifically, the study investigates the association that subsists between firm social responsibility and stock price market.

The data for this study were gathered from secondary source which were from the audited financial records as well as accounts of the listed companies in Nigeria. The study is highly descriptive and empirical as it embraces the use of panel regression technique as tool of analysis.

The findings of regression analysis confirm as a whole that firm social responsibility is not correlated to stock price market. It also discovered that corporate social responsibility could not be influenced by stock price market. The paper recommends that those who are saddled with responsibility should draw a line of distinction between factors that affect CSR from stock price market in order to achieve organizational goals and satisfy different stakeholders.
\end{abstract}

Keywords: Firm Social Responsibility Disclosure, Financial Performance, Stakeholders Hypothesis

\section{Introduction}

A corporate organization is established to maximize its stockholders' wealth. Therefore, maximization of wealth is a product of maximization of the value of a corporate organization. In the course of pursuing this desirable goal of increasing firm value, firm's activities and operations may bring about adverse effects on other stakeholders. For instance, the zoning of banking industries to a particular location may lead to some social vices and security challenges to other stakeholders living within the area. This is peculiar to most of cities in West African countries. In the same vein, establishment of industries or mining companies may pose some environmental damages and vices while corporate firms are striving to increase firm value. If these social pollution and footstep are not properly attended to, it may call for relocation of such industries or diverse allegations and agitation of various 
INTERNATIONAL JOURNAL OF ACADEMIC RESEARCH IN BUSINESS AND SOCIAL SCIENCES Vol. 8, No. 7, July 2018, E-ISSN: 2222-6990 @ 2018 HRMARS

groups of stakeholders. Some so called firms can equally engage in adverse tax avoidance and tax evasion in order to increase capital base or returns at expense of government.

Therefore, it is imperative for firm to consider other stakeholders while making effort to achieve organizational goal and objectives. Wang (2010) asserts that as a result of environmental pollution and damages people are displeased with unethical behavior of firm while pursuing their goals. Besides, different schools of thought have argued in favor of and against corporate social responsibility. For instance, expedient school of thought asserts that the major reason of establishment of a corporate firm is to exploit the shareholders' resources while pristine capitalist school of thought opines that the single purpose of an organization's creation is to minimize cost and maximize the shareholders' wealth and attain its targeted returns. However, Proponent of the social contract school argues that a corporate company builds up at the spirit of its surrounding; therefore it has task and obligation to respond to the needs of its stakeholders (Gray, Javad, Power \& Sinclair, 2001; Gray, Owen \& Adams, 1996).

From above arguments, it shows that there is a conflicting and inconclusive result regards relationship that exists between organization's pursuit and corporate social responsibility. Beside, most existing studies centered mainly on profitability rather than other aspects. It is obvious that issue of corporate social responsibility is wider than issue of profitability only. Furthermore, most prior studies relating to the topic were carried out in foreign countries using different methods for its analysis. For instance, Emilson (2012) studies the relationship between CSR and profitability using economic value added (EVA). Mittal, Sinha, and Singh (2008) researched into the correlation between CSR and organizational profitability using economic value added (EVA) and market value added (MVA) for empirical analysis. This indicates there is dearth of such paper in Nigeria. Thus, this paper is motivated to examine stock market price and corporate social responsibility of selected listed companies in Nigeria.

This study promises to examine the subject matter- stock price and corporate social responsibility of selected listed companies in Nigeria- using of panel regression technique as tool of analysis on the data gathered from the Nigeria stock market for the relevant years $2011-2017$. It investigates relationship between corporate social responsibility and elements of stock market price such as stock price, dividend, and stock price return. The study covers year 2011, being the period when IFRS was fully adopted in Nigeria, and 2017, being the most current published financial statements year. This is done in order to investigate whether the same result will be obtained with prior studies carried out in both advanced countries and developing countries.

The remaining parts of study is prepared as follows: section 2 investigates associated literature on corporate social responsibility, theoretical framework, and empirical reviews of previous studies showing the impact of the stock market price on corporate social responsibility and presents our hypotheses. Section 3 explains the operationalization and methodology for essential corporate social responsibility score, analyzing and testing the study's hypotheses. Section 4 reveals and discusses the outcomes and, section 5 presents the conclusions/recommendations.

\section{Literature Review}

\section{Firm Social Responsibility}

Firm social responsibility involves discussing the social influence of firm's economic actions to the recognized interest groups within the community. According to Kalu (2014), corporate social responsibilities can be classified into direct and indirect responsibilities. He argues that direct responsibilities are responsibilities which a firm owes to those who are directly influenced by the 
INTERNATIONAL JOURNAL OF ACADEMIC RESEARCH IN BUSINESS AND SOCIAL SCIENCES Vol. 8, No. 7, July 2018, E-ISSN: 2222-6990 @ 2018 HRMARS

firm. These are individuals within the control of entity. Direct responsibility is subdivided into two, namely: internal direct responsibility and external direct responsibilities. Internal direct responsibility refers to the responsibility owes to those who are within the firm in accordance with organizational culture, mission and objectives. External responsibilities are responsibilities owe to local communities and different clients. Indirect responsibilities are those responsibilities entity owes to other stakeholders outside the firm. The activities of those stakeholders are not controllable by the firm. He argues that their activities need to be complied with so that firm can obtain high level of public respect and confidence (ICAN, 2014).

In addition, Carroll (1999) supposes that every company has four responsibilities to its environment namely: legal dimension, economic dimension, ethical dimension, and discretionary or philanthropic dimension. Carroll (1999) is also of the opinion that a firm involves in ethical dimension when it obeys the code of ethics established by organizational members. A Firm engages in economic dimension when it distributes its resources to all stakeholders in the best equitable manner; while it involves in discretionary or philanthropic dimension when it contributes to the welfare of the community. The paper argues that firm engages in legal dimension when it obeys environmental laws and regulation. KPMG (2005) asserts that CSR should be given attention as a result of its importance which deals with the economic, environmental and social measurement of corporate performance.

Obi (2013) declares that Nigerian firms have been perceived to engage in firm social responsibility as the entity philanthropy focused on social economic development challenges. He argues that firm social responsibilities are still at an elementary stage in Nigeria. Robins (2011) argues that only aggressive corporate social responsibility activities could assist firms profit in achieving a potential listing in the stock market which in turn could aid the firm's stock price thus making stock option and executive stock more profitable. However, Ajide and Adetunji (2014) argue that corporate organizations which involve in social accountability acquire more cost since they consider organization social responsibility as a public relation deed used by big firms to look healthy before their customers and other stakeholders. In the light of huge cost incurred by firms in Nigeria yearly on firm social responsibility, it has been viewed that firm social responsibility could increase profit.

The European commission (2006) sees corporate social responsibility as a concept by which organizations incorporate social and environmental responsibility into their business culture, structure and practices, and in their interaction with different stakeholders on a deliberate basis. Maigana and Ferrell (2004) view CSR as a mechanism to raise organizations' legitimacy in the attendance of the stakeholders and to create a positive social responsibility and good reputations.

\section{Relationship between market stock price and corporate social responsibility}

Dornean and Oanea (2016) argue that stock price stands as the major market driver for the corporate social responsibility of a corporate organisation, whereas stock return and dividend have a neutral connection. Flammer (2012) examines corporate social responsibility and Stock Prices found that there is positive relationship between stock market and corporate social responsibility. The paper notices that response to ecological initiatives has come down over a period of time. This implies that the negative feedback to eco-harmful performance has become more downbeat. Flammer (2012) argues that a corporate firm's ecological footprint can influence stock prices.

\section{Factors that influence share price}

According to Fakunle (2010) certain factors might responsible for fall in share price include: the manner at which company's objectives are pursued; failure to give attention to environmental 
INTERNATIONAL JOURNAL OF ACADEMIC RESEARCH IN BUSINESS AND SOCIAL SCIENCES Vol. 8, No. 7, July 2018, E-ISSN: 2222-6990 @ 2018 HRMARS

matter despite its impressive performance; constant polluted air which is capable of causing health hazard; non compliance with social and environmental regulations; litigation; failure to comply with international standards and relevant standard of operation; non disclosure of relevant necessary financial information; and depletion of land and spillage of oil.

However, some researchers believe that stock price market could be influenced by corporate firm's return on asset, profitability, leverage and other elements of financial statements. For instance, According to Osifo and Fasua (2017), a firm's value is determined by its revenue strength such as its ability to make returns from turnover (net profit margin), and its capacity to invest in its resources to boost sales, as well as the firm's competence to minimize its costs, which amounts to its profitability growth. The paper argues that a firm with high profitability from assets can detain greater part of its net annual profits to finance its needs and thus less dependence on debt, but by deducting debt interest expense.

\section{Empirical Reviews of Previous Studies}

Ruf, Muralidhar, Brown, Janney and Paul (2001); Soloman and Hansen (1985); Pava and Krausz (1996); Preston and O'Bannon (1997) argue that CSR has a significant positive relationship with financial performance in terms of reputation and image (Schnietz \& Epstein, 2005) in terms of positive implication on the cost of debt (Izzo \& Magnanelli, 2012). Verschoor (1998); and Stanwick and Stanwick (1998) underscore that a good corporate social responsibility practice has a positive association with stakeholders in general.

However, McWilliams and Siegel (2000); Anderson and Frankle (1980); Elsayed and Paton, (2005) argue that there is no association between corporate performance and corporate social responsibility. Statman (2000) examined socially responsible mutual funds, discovered a neutral connection with the financial market's inability to put a monetary value on firms' responsible performance. To Derwall, Guenster, Bauer and Koedijk (2005) corporate social responsibility might not be expected for existing market models to determine effectively the influence of firm social responsibility on firms' portfolio performances.

Besides, Freedman and Jaggi (1982); Waddock and Graves (1997); Marcoux (2000); Sternberg (2000); and Preston and O'Bannon (1997) are of the opinion that of CSR has a negative association with firm performance. They argued that those who are saddled with responsibility can reduce funding corporate social responsibility so as to boost short term profitability and managers' compensation. Sternberg (2000) studied just business: business ethics in action, argues that stakeholder assumption "effectively destroys business accountability ... because a business that is accountable to all, is actually accountable to none".

\section{Review of Theories}

\section{Stakeholder theory and corporate social responsibility}

Fiori, Di Donato and Izzo (2015) argue that among the most pertinent subjects of corporate social responsibility, two key issues arise regarding the area of firm's responsibilities, such as: What is the corporate firm responsible for? And whom is the corporate firm responsible to? In accordance to the existing literature, there are two key responses: (1) the corporate firm is accountable only towards its shareholders as well as for this rationale, its ultimate objective is to boost its economic value; (2) the accountability of entity is the maximization of stakeholders' value. Therefore, those who are charged with responsibility have to please numerous groups who have some stakes or interest in an entity and can affect its decisions. 
INTERNATIONAL JOURNAL OF ACADEMIC RESEARCH IN BUSINESS AND SOCIAL SCIENCES Vol. 8, No. 7, July 2018, E-ISSN: 2222-6990 @ 2018 HRMARS

Freeman (1984) is of the opinion that a stakeholder is any person who can influence or is influenced by the attainment of the firm's objectives. Regarding the solutions (1), traditional finance theory argues that shareholders value maximization has to be the best interest of those who are charged with responsibility (Jensen and Meckling, 1976; Ross, 1973; ICAN, 2014). In this logic, the Shareholder Theory holds that the corporate social accountability should be viewed only via the lens of the returns maximization ethic (Grant, 1991; Lazonick \& O'Sullivan, 2000; Kotter \& Heskett, 1992; Delves, 2003).

However, shareholders mechanism is short satisfying sufficient in order to elucidate firm' behaviors, since the maximization of the shareholders value occasionally does not lead to long term profitability or interests' alignment mechanisms rather than short term profitability decisions, therefore resulting to economic insecurity or instability. The Stakeholder hypothesis and its importance on the position of dissimilar stakeholders in the worth creation trail, seems to conduit this gap. In accordance to this assumption, firm's accountability is multiple and executive directors have to please diverse necessities of numerous stakeholders (Freeman, 1984; Freeman \& Velamuri, 2006).

By analyzing and balancing the stakes of various stakeholders, the executive can boost firm's efficiency and generate value. In this situation, corporate social responsibility is viewed as a strategic means in order to please stakeholders' expectations. Blowfield and Murray (2008) underscore that Freeman failed to set the Stakeholder assumption against the Shareholder one. The study used an instrumental mechanism to Stakeholder Theory, arguing that firms select their prime stakeholders on the opinion of their potential responsibility in jeopardizing the companies' survival (Phillips, 2003; Husted \& Salazar, 2006). In conclusion, they argue that there is no intrinsic antagonism between the Stakeholder Theory and Shareholder Theory regarding corporate social responsibility issues, value making and firm's performance. These theories can be regarded an instrument to boost the organization's performance such as: financial, operational, social and to generate value.

Consequently, this study has the following recommendation: corporate organization should make effective provision for carrying out result-oriented social responsibility. This can be effective when an entity offers sufficient welfare of management via incentives so as to support them to disclose corporate social responsibility activities. Besides, the study is of opinion that more researches should investigate to clarify the contradiction of previous results in expatiating association between corporate social responsibility and leverage.

\section{Methodology}

The data for this paper were collected from secondary source which obtained from the audited financial statements together with records of the listed Deposit Money Banks in Nigeria. The entire population of the paper involves of entire companies enlisted on the floor of Nigeria Stock Exchange which were grouped into four, namely: manufacturing, oil and gas, services and agriculture. This demonstrated in order to analyze whether firm with higher CSR disclosure rating are more appreciated and influenced by market stakeholder. The study is highly descriptive and empirical in form as it supports the exploit of panel regression method as instrument of analysis. The main reason for this analysis is to examine whether the CSR conduct impacts on a firm stock price, we used the similar methodology applied in some of previous researches ( Dornean \& Oanea, 2016; Osifo \& Fasua, 2017). 
INTERNATIONAL JOURNAL OF ACADEMIC RESEARCH IN BUSINESS AND SOCIAL SCIENCES

Vol. 8, No. 7, July 2018, E-ISSN: 2222-6990 @ 2018 HRMARS

\section{Data and Descriptive Statistics}

In our analysis we utilized all the companies listed at Nigeria Stock Exchange (NSE), by grouping all the companies into four, namely: manufacturing, services, agriculture and, oil and gas. This is allowed in order to give equal chance to all available firms on the floor of Nigeria Stock Exchange. Selected companies were picked out of each strata and weight average data were also obtained where we derived data for stock price, dividend, and stock price return for the relevant years 2011 to 2017. As earlier stated, we use the latest reports on the floor of NSE which are assessable to us, 2017 and from 2011 (year of IFRS adoption in Nigeria). All the data utilized in the analysis are computed from these relevant years.

Table 1. Descriptive statistics for analyzed variables

\section{Manufacturing companies}

Date:

$04 / 26 / 18$

Time: 03:59

Sample: 20112017

\begin{tabular}{lccc}
\hline \hline & SP & DIV & SPR \\
\hline \hline Mean & 141.9443 & 30.68571 & 0.176542 \\
Median & 147.0000 & 32.00000 & 0.081019 \\
Maximum & 167.9000 & 38.00000 & 1.000000 \\
Minimum & 94.42000 & 22.70000 & -0.215441 \\
Std. Dev. & 24.57443 & 6.332306 & 0.405740 \\
Skewness & -0.937727 & -0.239791 & 1.281999 \\
Kurtosis & 3.123323 & 1.553342 & 3.526180 \\
& & & \\
Jarque-Bera & 1.030322 & 0.677489 & 1.998195 \\
Probability & 0.597404 & 0.712664 & 0.368212 \\
Observations & 7 & 7 & 7
\end{tabular}

\section{Agricultural companies}

Date:

04/26/18

Time: 04:23

Sample: 20112017

\begin{tabular}{lccc}
\hline \hline & SP & DIV & SPR \\
& & & \\
\hline \hline Mean & 88.18571 & 31.80000 & 0.372765 \\
Median & 87.00000 & 30.30000 & 0.131614 \\
Maximum & 151.2000 & 55.00000 & 1.000000
\end{tabular}


INTERNATIONAL JOURNAL OF ACADEMIC RESEARCH IN BUSINESS AND SOCIAL SCIENCES Vol. 8, No. 7, July 2018, E-ISSN: 2222-6990 @ 2018 HRMARS

$\begin{array}{lrrr}\text { Minimum } & 0.800000 & 19.30000 & -0.019540 \\ \text { Std. Dev. } & 47.75261 & 11.20238 & 0.438624 \\ \text { Skewness } & -0.561765 & 1.304275 & 0.761601 \\ \text { Kurtosis } & 2.900863 & 3.906967 & 1.791810 \\ & & & \\ \text { Jarque-Bera } & 0.371043 & 2.224579 & 1.102462 \\ \text { Probability } & 0.830671 & 0.328805 & 0.576240\end{array}$

$\begin{array}{llll}\text { Observations } & 7 & 7 & 7\end{array}$

\section{Services companies}

Date:

$04 / 26 / 18$

Time: 04:36

Sample: 20112017

\begin{tabular}{lrrr}
\hline \hline & SP & DIV & \multicolumn{1}{c}{ SPR } \\
\hline \hline Mean & 2.998571 & 13.68571 & -0.471607 \\
Median & 4.400000 & 4.900000 & 0.000000 \\
Maximum & 4.400000 & 32.40000 & 1.000000 \\
Minimum & 1.130000 & 0.700000 & -2.893805 \\
Std. Dev. & 1.747889 & 14.09721 & 1.697840 \\
Skewness & -0.288675 & 0.363365 & -0.788607 \\
Kurtosis & 1.083333 & 1.278301 & 1.824906 \\
& & & \\
Jarque-Bera & 1.168692 & 1.018612 & 1.128299 \\
Probability & 0.557470 & 0.600913 & 0.568844
\end{tabular}

Observations

7

7

7 
INTERNATIONAL JOURNAL OF ACADEMIC RESEARCH IN BUSINESS AND SOCIAL SCIENCES

Vol. 8, No. 7, July 2018, E-ISSN: 2222-6990 @ 2018 HRMARS

\section{Oil and gas}

Date:

$04 / 26 / 18$

Time: 04:40

Sample: 20112017

\begin{tabular}{lccc}
\hline \hline & SP & DIV & SPR \\
& & & \\
\hline \hline Mean & 61.71000 & 4.600000 & 0.302179 \\
Median & 31.19000 & 4.700000 & 0.182270 \\
Maximum & 136.9000 & 5.800000 & 1.000000 \\
Minimum & 21.02000 & 3.700000 & -0.267593 \\
Std. Dev. & 47.39789 & 0.945163 & 0.413775 \\
Skewness & 0.580902 & 0.272479 & 0.430658 \\
Kurtosis & 1.690730 & 1.490463 & 2.373418 \\
& & & \\
Jarque-Bera & 0.893660 & 0.751240 & 0.330887 \\
Probability & 0.639653 & 0.686863 & 0.847518 \\
& & & 7 \\
Observations & 7 & 7 & 7
\end{tabular}

For each stratum we obtained these variables as follows:

- $\quad$ Stock price - weight average stock price from year 2011 - 2017.

- Dividend value - dividend figure in 2011 - 2017.

- Stock price return - ratio between the difference of final and initial stock price and the initial stock price, based on relation.

Table 2 shows the descriptive statistics for the chosen variables, from where we are able to observe a definite result of different analysed groups: CSR of Manufacturing, Agricultural, Service, and Oil and gas companies.

At a first glance, we can view that CSR of various firms' weight average stock prices for the manufacturing CSR, agricultural CSR, service CSR and, oil and gas CSR which include: 141.94, 88.19, 2.99, and 61.71 respectively. Manufacturing firm has highest value. Also average dividend value per share for the manufacturing CSR, agricultural CSR, service CSR and, oil and gas CSR are: 30.6, 31.8, 13.68, and 4.6 respectively. In the same vein, when we analysed the stock return for these 4 groups, CSR manufacturing, agricultural, service and, oil and gas companies recorded $18 \%, 37 \%,-47 \%$, and $30 \%$ respectively in their stock prices, we discovered agricultural firm has the highest followed by oil and gas companies.

Model Specification:

As part of efforts to evaluate Stock Price Market and Corporate Social Responsibility of Selected Listed Companies in Nigeria, a multiple regression model was structured. The model displays the level of the association: the explanatory variables put forth on the dependent variable.

$\mathrm{CSR}=\beta_{0}+\beta_{1} \mathrm{SP}_{\mathrm{it}}+\beta_{2} \mathrm{DIV}_{\mathrm{it}}+\beta_{3} \mathrm{SPR}_{\mathrm{it}}+\varepsilon$ 
INTERNATIONAL JOURNAL OF ACADEMIC RESEARCH IN BUSINESS AND SOCIAL SCIENCES

Vol. 8, No. 7, July 2018, E-ISSN: 2222-6990 @ 2018 HRMARS

Where CSR = corporate social responsibility measured using CSR disclosure index

- SP - weight average stock price from year 2011 - 2017.

- $\quad$ DIV - dividend figure in 2011 - 2017.

- SPR- ratio between the difference of final and initial stock price and the initial stock price, based on relation.

$\beta_{1}-\beta_{3}=$ are the coefficient of the parameter estimate

Data Presentation and Analysis

Operationalization of Variables

The variables in use, are operationalized as follows:

\begin{tabular}{|c|c|c|c|c|}
\hline$S / N$ & Variables & Operational definitions & Source & $\begin{array}{l}\text { Apriori } \\
\text { sign }\end{array}$ \\
\hline & $\begin{array}{l}\text { Dependent } \\
\text { variable: }\end{array}$ & $\begin{array}{l}\text { Equal to } 1 \text { when firm engaged in CSR } \\
\text { while } 0 \text { otherwise. }\end{array}$ & & \\
\hline 1 & $\begin{array}{l}\text { corporate } \\
\text { social } \\
\text { responsibility }\end{array}$ & $\begin{array}{l}\text { corporate social responsibility } \\
\text { measured using CSR disclosure index } \\
\text { awareness in financial statements } \\
\text { and its contributions }\end{array}$ & $\begin{array}{l}\text { Revert (2016); Osifo } \\
\text { \& Fasua, } 2017\end{array}$ & Ve \\
\hline & $\begin{array}{l}\text { Independent } \\
\text { variables: }\end{array}$ & & & \\
\hline 1 & SP & $\begin{array}{l}\text { Stock price measured as the } \\
\text { weighted average of stock price }\end{array}$ & $\begin{array}{l}\text { Reverte, 2016; Wang } \\
\text { \& Li, } 2016\end{array}$ & $+\mathrm{Ve}$ \\
\hline 2 & DIV & $\begin{array}{l}\text { Dividend measured as weighted } \\
\text { average of total dividend paid }\end{array}$ & $\begin{array}{l}\text { Dornean \& Oanea, } \\
2017 .\end{array}$ & +ve \\
\hline 3 & SPR & $\begin{array}{l}\text { Stock price return measured as ratio } \\
\text { between the variance of latter and } \\
\text { former years stock and the former } \\
\text { year stock price as a base variable }\end{array}$ & $\begin{array}{l}\text { Dornean \& Oanea, } \\
2017 .\end{array}$ & $\begin{array}{l}+ \text { and - } \\
\text { ve }\end{array}$ \\
\hline
\end{tabular}

Source: Researcher's compliance, 2018.

This section contains the analysis and result presentation of the data collected from the Nigerian Stock Exchange. 
INTERNATIONAL JOURNAL OF ACADEMIC RESEARCH IN BUSINESS AND SOCIAL SCIENCES

Vol. 8, No. 7, July 2018, E-ISSN: 2222-6990 (C) 2018 HRMARS

Table 3

\section{Combine of selected 4 groups}

Date:

$04 / 26 / 18$

Time: 09:33

Sample: 128

\begin{tabular}{lcccc}
\hline \hline & CSR & SP & DIV & SPR \\
& & & & \\
\hline \hline Mean & 0.678571 & 73.70964 & 20.19286 & 0.094970 \\
Median & 1.000000 & 83.90000 & 23.10000 & 0.122216 \\
Maximum & 1.000000 & 167.9000 & 55.00000 & 1.000000 \\
Minimum & 0.000000 & 0.800000 & 0.700000 & -2.893805 \\
Std. Dev. & 0.475595 & 61.12221 & 14.78668 & 0.934914 \\
Skewness & -0.764719 & 0.087769 & 0.190554 & -2.263960 \\
Kurtosis & 1.584795 & 1.452668 & 2.102555 & 8.214262 \\
& & & & \\
Jarque-Bera & 5.065650 & 2.829226 & 1.109092 & 55.63902 \\
Probability & 0.039434 & 0.243020 & 0.574333 & 0.000000 \\
Observations & 28 & 28 & 28 & 28
\end{tabular}

The table 3 shows the descriptive statistics of 4 organizations selected. An analysis of the result shows that CSR revealed a mean value of 0.678 therefore stating that on the average of $69 \%$ of sample of listed companies disclosed their degree of obligation to corporate social responsibility performance. This shows 0.0000 and 1.00000 , elucidating in the minimum and maximum values accordingly. The standard deviation evaluated the spread of the distribution was at figures of 0.475595 . The Jarque Bera statistics stood at 5.065650 with a significance probability of 0.039

Table 4 Dependent Variable: CSR

Method: Least Squares

Date: 04/26/18 Time: 10:03

Sample: 128

Included observations: 28

\begin{tabular}{crrrr}
\hline \hline \multicolumn{1}{c}{ Variable } & $\begin{array}{r}\text { Coefficien } \\
\mathrm{t}\end{array}$ & Std. Error & t-Statistic & Prob. \\
& & & \\
\hline \hline C & 0.000000 & $4.78 \mathrm{E}-15$ & 0.000000 & 1.0000 \\
PS & 1.000000 & $5.00 \mathrm{E}-17$ & $2.00 \mathrm{E}+16$ & 0.0000 \\
DIV & 1.000000 & $2.05 \mathrm{E}-16$ & $4.88 \mathrm{E}+15$ & 0.0000 \\
SPR & 1.000000 & $2.87 \mathrm{E}-15$ & $3.48 \mathrm{E}+14$ & 0.0000 \\
\hline \hline R-squared & 1.000000 & Mean dependent var & 93.99747 \\
Adjusted R-squared & 1.000000 & S.D. dependent var & 69.52783 \\
S.E. of regression & & Sum squared resid & 4.590027
\end{tabular}


INTERNATIONAL JOURNAL OF ACADEMIC RESEARCH IN BUSINESS AND SOCIAL SCIENCES

Vol. 8, No. 7, July 2018, E-ISSN: 2222-6990 @ 2018 HRMARS
F-statistic
Durbin-Watson stat
0.879142
2.280032
Prob(F-statistic) $\quad 0.000000$

The table 4 shows that the regression sum of squares (1.380014) is less than the residual sum of squares (4.590027), which disclosed that more of the variation in the dependent variable is not explainable by the model. It was indicated that the F-statistic stood at 2.28003 with probability value of the F statistics $(0.000)$ is less than 0.05 , which explains that the variation disclosed by the model is not due to likelihood.

The correlation coefficient has a figure of 0.0000 , showing that the influences of total corporate social responsibility on stock price market were not significant with $\mathrm{R}$ square 1.000 the coefficient of determination, indicates that $100 \%$ of the variation in the CSR activities is explainable by the model; and the residual $5 \%$ is reported for, being elucidated by the stochastic error term. The Durbin Watson statistics is 0.879142 value

Base on individual coefficient, it was experimental that stock price, dividend, and stock price returns coefficients are: $1.00,1.00$, and 1.000 respectively ( $t=478,2.05$, and 2.87 accordingly). This implies that there is a positive connection between the stock price, dividend and stock price returns, and corporate social responsibility; this depicts that stock price, dividend, and stock can determine the level of corporate social responsibility.

\section{Conclusions}

The objective of this study was to examine whether the result of this paper outcome similar with the previous papers carried out in advanced countries and to expand frontier of knowledge. It also sought to evaluate the connections between stock prices market and firms' social responsibilities, and their performance regarding price stock and dividend paid, for listed companies on Nigeria Stock Exchange from 2011 to 2017.

The whole listed companies are grouped into 4 strata on analysis was run. On applying the statistical models, we discovered that collectively CSR activities have zero relationship with stock prices market which is constant with Mishra and Modi (2016); McWilliams and Siegel (2000); Anderson and Frankle (1980); Elsayed and Paton, (2005); Derwall, Guenster, Bauer and Koedijk (2005). While individual variable result, shows that each element on its own influences the CSR. (but not as a whole unit). This is supported and constant with Revert (2016).

Our paper is limited in that the analysis is carried on only the companies listed on the Nigeria Stock Exchange. The further investigation can be carried out the following areas: the analysis via the different independent variables such as: ROE, debt to equity ratio, working capital ratio, as well as ear. It would be appealing to examine the association between corporate social responsibility and market stock price pre, during and post the current financial predicament.

\section{References}

Ajide, F. M., \& Adetunji, A. A. (2014). The effects of corporate social responsibility activity disclosure on corporate profitability: Empirical evidence from Nigerian commercial banks. IOSR Journal of Economics and Finance, 2(6): $17-25$

Anderson, J., \& Frankle, A. (1980). Voluntary social report: An iso-beta portfolio Analysis. Accounting Review, 55. 
INTERNATIONAL JOURNAL OF ACADEMIC RESEARCH IN BUSINESS AND SOCIAL SCIENCES Vol. 8, No. 7, July 2018, E-ISSN: 2222-6990 (C) 2018 HRMARS

Blowfield, M., \& Murray, A. (2008). Corporate responsibility: a critical introduction. Oxford: Oxford University Press)

Carroll, B. A. (1999). Corporate social responsibility: Evolution of a definitional construct. Business \& society

Derwall, J., Guenster, N., Bauer, R., \& Koedijk, K. C. G. (2005). The eco-efficiency premium puzzle. Financial Analysts Journal, 61.

Dornean, A., \& Oanea, D. C. (2017). CSR and company's stock price: A comparative evidence from Bucharest stock exchange. EuroEconomica, 36(1).

Dornean, A., \& Oanea, D.C. (2016). The impact of CSR on company's stock price: Evidence from Bucharest stock exchange. The Proceedings of the 27th International Business Information Management Association Conference, Innovation Vision 2020: From Regional Development Sustainability to Global Economic Growth, 1:1027-1037.

Elsayed, K., \& Paton, D. (2005). The impact of environmental performance on firm performance: static and dynamic panel data evidence. Structural Change and Economic Dynamics, 16.

Emilson, L. M., Classon, M., \& Bredmar, K. (2012). Corporate social responsibility and the quest for profitability- Using economic value added to trace profitability. International Journal of Economics and Management Sciences, 2(3): 43-54.

Fakunle, B. (2010). Audit and assurance companion: Practice and revision kit. Lagos: Nigeria

Fiori, G., Di Donato, F., \& Izzo, M. F. (2015). Corporate social responsibility and stock prices: a study on the Italian market. Corporate Ownership \& Control, 12 (2) Winter.

Flammer, C. (2012). Corporate social responsibility and stock prices: The environmental awareness of sareholders. MIT Sloan School of Management

Freedman, M., \& Jaggi, B. (1982). Pollution disclosures, pollution performance and economic performance. Omega, $10(2)$

Freeman, R. E. (1984). Strategic management: A stakeholder approach. Englewood Cliffs, NJ: Prentice-Hall.

Freeman, R. E., \& Velamuri, R. (2006). A new approach to CSR: company stakeholder responsibility in A. Kakabadse, A., Morsing (eds.), corporate social responsibility (csr): reconciling aspirations with applications, Basingstoke Palgrave Macmillan.

Grant, C. (1991). Friedman fallacies. Journal of Business Ethics, 10. 
INTERNATIONAL JOURNAL OF ACADEMIC RESEARCH IN BUSINESS AND SOCIAL SCIENCES

Vol. 8, No. 7, July 2018, E-ISSN: 2222-6990 (C) 2018 HRMARS

Gray, R. H., Owen, D. L., \& Adams, C. (1996). Accounting and accountability, changes and challenges in corporate social and environmental reporting. Prentice Hall: Heme Hempstead.

Gray, R. H., Javad, M., Power, D., \& Sinclair, C. D. (2001). Social and environmental disclosures and corporate characteristics, a research note and extension. Journal of Business Finance \& Accounting, 28: 327-356.

Husted, B. W., \& Salazar J. D. (2006). Taking friedman seriously: maximizing profits and social performance, Journal of Management Studies, 43 (1).

I C AN. (2014). Study text: Management, government and ethics. United Kingom: Emile Woolf International Bracknell Ennterprise \& Innovation Hub.

Izzo, M. F., \& Magnanelli, B. S. (2012). The relation between CSR performance and the cost of debt

Jensen, M. C., \& Meckling, W. H. (1976). Theory of the firm: Managerial behavior, agency costs, and ownership structure, Journal of Financial Economics, 3.

Kalu, U. (2014). Advanced financial reporting and ethics. Lagos

KPMG. (2005). World class transactions survey: insights into creating shareholder value

Kotter, J., \& Heskett, J. (1992). Corporate culture and performance. New York: Free Press

Lazonick, W., \& O'Sullivan, M. (2000). maximizing shareholder value: a new ideology for corporate governance, Economy and Society, 29, 1.

Maignan, I., \& Ferrell, O. C. (2004). Corporate social responsibility and marketing: an integrative framework. Journal of Academic and management Science, 32(1), 3-19

McWilliams, A., \& Siegel, D. (2000). Corporate social responsibility and financial performance: correlation or misspecification? Strategic Management Journal, 21(5).

Mishra, S., \& Modi, S. B. (2016). Corporate social responsibility and shareholder wealth: The role of marketing capability. Journal of Marketing, 80(1): 26-46.

Mittal, R. K., Sinha, N., \& Singh, A. (2008). An Analysis of Linkage between Economic Value Added and Corporate Social Responsibility. Management Decision, 46 (9): 1437-1443

Obi, D. (2013). CRS: 8 banks spend \#1.9bn to make social impact. This Business day News paper. www.businessdayonline.com 
INTERNATIONAL JOURNAL OF ACADEMIC RESEARCH IN BUSINESS AND SOCIAL SCIENCES

Vol. 8, No. 7, July 2018, E-ISSN: 2222-6990 @ 2018 HRMARS

Osifo, U. I. O., \& Fasua, H. K. (2017). Social and environmental disclosure and holistic growth in the positive accounting theory (PAT) view. IOSR Journal of Business and Management, 19(6).

Pava, L., \& Krausz, J. (1996). The association between corporate social responsibility and financial performance. Journal of Business Ethics, 15.

Phillips, R. (2003). Stakeholder theory and organizational ethics. San Francisco: BerrettKoehler.

Preston, L., \& O’Bannon, D. (1997). The corporate social-financial performance relationship. Business and Society, 36 (1): 5-31.

Reverte, C. (2016). Corporate social responsibility disclosure and market valuation: evidence from Spanish listed firms. Review of Managerial Science, 10( 2): 411-435.

Robins, R. (2011). Does corporate social responsibility increase profit? Business ethics. The magazine of corporate social responsibility. www.business-ethics.com

Ross, S. (1973). The economy theory of the agency: The principal's problem. American economic Review, 63.

Ruf, B. M., Muralidhar, K., Brown, R. M., Janney, J. J., \& Paul, K. (2001). An Empirical investigation of the relationship between change in corporate social performance and financial performance: A stakeholder theory perspective. Journal of Business Ethics, 32.

Schnietz, K. E., \& Epstein, M. J. (2005). Exploring the financial value of a reputation for corporate social responsibility during a crisis. Corporate Reputation Review, 7 (4).

Soloman, R., \& Hansen, K. (1985). It's good business. New York: Atheneum.

Stanwick, P. A., \& Stanwick, S. D. (1998). The relationship between corporate social performance, and organizational size, financial performance, and environmental performance: An empirical examination. Journal of Business Ethics, 17

Statman, M. (2000). Socially responsible mutual funds, Financial Analysts Journal, 56.

Sternberg, E. (2000). Just business: Business ethics in action. Oxford: Oxford University Press

Verschoor, C. C. (1998). A study of the link between as corporation's

Waddock, S., \& Graves, S. (1997). The corporate social performance-financial performing linkage.Strategic Management Journal, 18 (4).

Wang, L. N. (2010). Empirical analysis on EVA: MVA index application. Finance and Accounting Monthly, 3: 43-45. 